\title{
1. The Diversity of Political Regimes
}

\author{
Sten Berglund and Joakim Ekman
}

The topic of this book is political cleavages in 19 countries in Central and Eastern Europe. The theoretical link between political stability and political cleavages is simple - the emergence of a stable party system and distinguishable and consistent voter preferences are typically seen as indicators of democratic consolidation (cf. Whitefield 2002; Krause 2004; Berglund and Ekman 2010). However, the topic of this volume is not just the consolidation of democracy in a post-communist setting, since the analysis will cover everything from full democracies to hybrid regimes and more or less authoritarian political regimes. The idea is rather to discuss the emergence of political cleavages and their consequences for political stability - in terms of regime continuity - in the eastern part of Europe. The analysis will thus not only add to our understanding about contemporary party-voter linkages in a post-communist setting, but also to our knowledge about regime dynamics in a region characterised by political diversity.

\section{A Diverse Picture of Political Development}

Since the publication of the previous editions of the Handbook of Political Change in Eastern Europe, in 1998 and 2004 respectively, we have witnessed a gradual stabilisation of political life in many places in Central and Eastern Europe. In the original study, from 1998, the sample included nine countries: Estonia, Latvia, Lithuania, Poland, the Czech Republic, Slovakia, Hungary, Slovenia, Romania and Bulgaria. Eight of these countries had already achieved full membership of the European Union (EU) in 2004, and Bulgaria and Romania followed suit in 2007. Despite some instances of corruption, populism and seemingly fragile political institutions, few would argue that these countries fail to meet basic democratic standards. The democratic regimes that were installed in Central and Eastern Europe following the demise of communism have thus been able to cope with a number of significant challenges in the 1990s and 2000s, 
and the relevant question in the 'new' EU member states today has little to do with the risk of democratic breakdown. Rather, it is a question of creating as favourable conditions as possible for the practical realisation of democracy. This process - usually referred to in the literature as the consolidation of democracy - is not fundamentally different from the dayto-day process of coping with the challenges to democracy in Western Europe. The main concern regarding the future development of democracy - in Europe as a whole - has to do with the deepening of democracy in the face of European integration, globalisation, fincial crises, the rise of xenophobia, and societal fragmentation, to mention just a few challenges to democracy in contemporary Europe (cf. Berglund, Duvold, Ekman and Schymik 2009).

However, 'stabilisation' has not always entailed democratic consolidation in the post-communist region. A striking feature of the post-1989 political developments in Central and Eastern Europe - including the territory of the former Soviet Union - is in fact the diversity of contemporary political regimes. The ten countries in Central and Eastern Europe that nowadays are members of the European Union and more or less stable democracies do in fact make up the exception rather than the rule. In the 2004 edition of the Handbook of Political Change in Eastern Europe, three countries were added to the original sample: Croatia, Serbia, and Moldova. Of these, the two former would perhaps qualify for the label 'consolidated democracy', but Moldova is an electoral democracy on a more basic level.

Generally speaking, Central Europe, the Baltic states and at least parts of South Eastern Europe thus represent the successful cases. Further to the east, Belarus and a number of former Soviet states in Eurasia are outright dictatorships. However, one of the most distinct characteristics of the postcommunist region is in fact the emergence of 'mixed' regimes, i.e. regimes caught in a grey zone between democracy and autocracy. In such 'hybrid' regimes, we typically find multiparty electoral competition combined with disrespect for human rights and civil liberties, notable levels of corruption, instances of harassment of the political opposition, as well as restrictions on the freedom of the press. In some ways, such grey zone regimes are close to (flawed) democracies, and in other ways, they resemble authoritarian systems more than anything else.

The literature on semi-democracies/semi-autocracies has expanded in recent years. Still, mixed or hybrid regimes - as such - are not really new. Diamond acknowledges the existence of 'multiparty, electoral, but undemocratic regimes' in Singapore, Malaysia, South Africa and a few countries in Latin America already in the 1960s and 1970s (Diamond 2002, 23); and in a similar manner, analysing multi-party politics in Central and Eastern Europe of 1900-1939, Schöpflin concludes that 'governments did not lose elections' (Schöpflin 1993, 12). The exceptions, Hungary in 1905 and Bulgaria in 1932, are attributed to divisions within the elite rather than 
the popular will. The discussion about hybrid regimes has its intellectual foundation in the transition paradigm and - somewhat paradoxically - in the explicit critique of this very paradigm (McFaul 2002; Carothers 2002). What the transitologists told us, when analysing seemingly drawn-out democratisation processes in Latin America, was basically that transitions could produce a democracy but also end with a 'softer' authoritarian regime, dictablanda, or a restrictive, illiberal democracy, referred to as democradura (O'Donnell and Schmitter 1986). In this context, already in the early 1990s, scholars like Philippe Schmitter and Terry Lynn Karl wrote about hybrid regimes in Central America, as well as in Africa (Schmitter 1994; Karl 1995). The current debate on electoral authoritarianism is linked to recent empirical observations of authoritarian backlashes in countries where democratisation was expected or at least hoped for, i.e. in postcommunist Europe and Eurasia. The notion of electoral authoritarianism and 'mixed' systems slowly gained recognition among scholars of Eastern Europe. In 2001, Lilia Shevtsova explicitly identified Russia under Putin as a hybrid regime:

In sum, Russia has a hybrid regime, founded on the principle of weakly structured government and relying on both personalistic leadership and democratic legitimation. This combination of incompatible principles enables the regime to develop simultaneously in various directions: toward oligarchy, toward authoritarianism, and toward democracy as well. Yet such a regime can hardly be consolidated; its contradictory tendencies are a sure recipe for instability (Shevtsova 2001, 67).

However, the real breakthrough for the concept of hybrid regimes was in 2002 when the Journal of Democracy published a topical issue on elections without democracy, including Diamond's often cited piece 'Thinking About Hybrid Regimes'. The same issue included Levitsky and Way's 'The Rise of Competitive Authoritarianism', thus suggesting another buzzword (Levitsky and Way 2002). Still, the label hybrid regime - meaning competitive or electoral authoritarianism - seems to have stuck, as it is short, simple and snappy. In recent years, we have seen work on hybrid regimes in Southeast Asia (Case 2005; Wang 2009; Alexander 2008), in the Middle East (Ryan and Schwedler 2004), in the Caucasus (Wheatley and Zürcher 2008), and in Africa and South America (Ekman 2009). In 20062007, the Intelligence Unit of the Economist included 'hybrid' regimes as one of the categories in its worldwide Index of Democracy. Furthermore, we have seen more general attempts to map out hybrid regimes in the world (Wigell 2008; Boogards 2009; Ekman 2009). As for monographs, Schedler (2006) and Levitsky and Way (2010) are among the best currently on the market. However, there are as yet only few works that explicitly address the issue of stability. In particular, there is a lack of actual empirical assessments of the stability and performance of hybrid regimes. 
One notable exception is Morlino's recent article demonstrating the survival potential of surprisingly my hybrid regimes (Morlino 2009). Analysing continuity and change among hybrid regimes during the time period 1989-2007, he found no less than 26 'stable hybrid regimes', i.e. regimes that had been 'partially free' for 15 years or more, and nine cases of 'less persisting hybrid regimes' where the regime had survived for more than ten years without any change of regime. Among the 35 hybrid regimes identified, only ten made transitions; to democracy (7) or authoritarianism (3). Recent studies show that hybrid regimes that employ more or less competitive elections are more likely to make transitions than other regimes (Hadenius and Teorell 2007; Howard and Roessler 2006; Roessler and Howard 2009). But all hybrid regimes clearly cannot be dismissed as merely transitional phenomena. As noted by Merkel, hybrid regimes, or 'defective democracies' as he labels them, are able to form stable links to their environment and are often accepted by elites as well as citizens at large as adequate solutions to the manifold problems that are present in postauthoritarian societies (Merkel 2004).

\section{Regime Trajectories}

In order to empirically demonstrate the occurrence of democratic, authoritarian and hybrid regimes in the post-communist part of Europe, we need an instrument. Drawing on Linde and Ekman (2011), our operationalisation of political regimes is straightforward and relies on secondary data provided by the Freedom House ratings of civil liberties and political rights. Freedom House rates countries on a scale from 1 (most free) to 7 (least free) on both dimensions. The two scores are added and divided by two in order to come up with a mean rating including both civil liberties and political rights for each country and year. Countries with a score between 1 and 2 are classified as 'democracies'. Countries with scores from 2.5 to 5 are labelled as 'hybrid regimes' and countries with scores of 5.5 or higher are referred to as 'autocratic'. This operationalisation corresponds well with one of the most cited theoretical definitions of hybrid regimes, provided by Levitsky and Way (2010, 5-6). According to Levitsky and Way, competitive authoritarian regimes (which is the label they use) are:

civilian regimes in which formal democratic institutions exist and are widely viewed as the primary means of gaining power, but in which incumbents' abuse of the state places them at significant advantage vis-à-vis their opponents. Such regimes are competitive in that opposition parties use democratic institutions to contest seriously for power, but they are not democratic because the playing field is heavily skewed in favor of incumbents. Competition is thus real but unfair (Levitsky and Way 2010, 7). 
Hybrid regimes thus have meaningful competitive elections, but the abuse of state resources by incumbents violates at least one of three defining attributes of democracy: free and fair elections, respect for civil liberties and political rights, and a level political playing field (Levitsky and Way 2010, 7). These attributes also constitute the foundation of the 'political rights' and 'civil liberties' ratings by Freedom House.

Figure 1.1: Post-communist regimes (1992-2008)

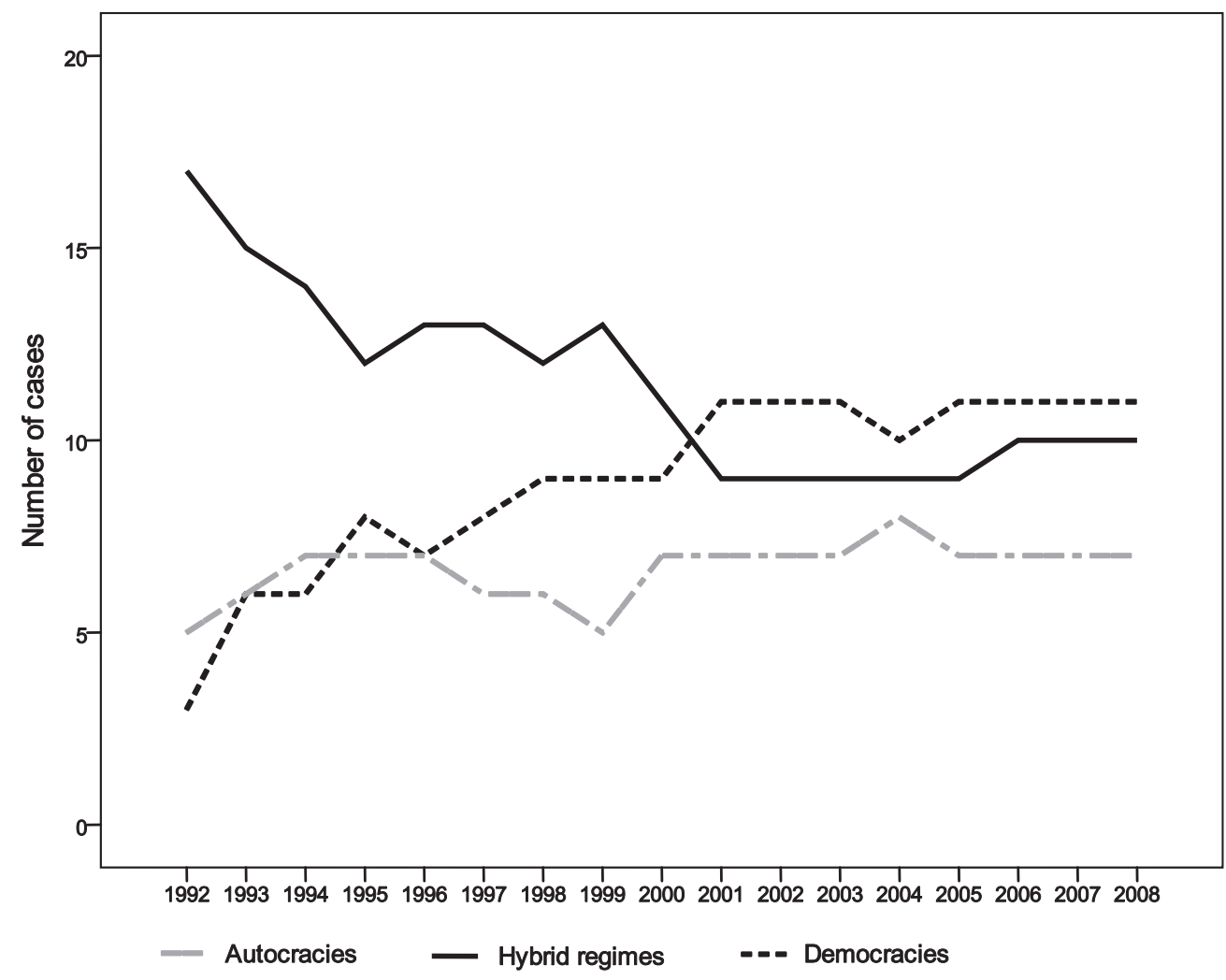

Source: Linde and Ekman (2011).

Our universe of cases includes all political regimes in 29 post-communist countries. It begins in the year 1992 and extends until 2008. The unit of analysis is the type of political regime in any given country and year. The total number of cases is 460. Thus, applying the classification described above - democracies, hybrid regimes, and autocracies - we end up with 460 instances of post-communist regimes (country-years).

Figure 1.1 illustrates the development of post-communist regimes over time. As we can see, most countries embarked on their post-communist journey as hybrid regimes. Due to the relatively rapid democratisation in Central and Eastern Europe, the number of hybrid regimes decreased substantially during the 1990s. In the last decade, however, all three regime types have been quite stable in terms of the actual number of regimes. 
Figure 1.1 depicts the situation on the aggregated level. What about regime trajectories in single countries? Although not displayed in Figure 1.1, it may be noted that only four countries - the Czech Republic, Hungary, Poland and Slovenia - have been democracies throughout the whole period. Six countries - Armenia, Albania, Georgia, Macedonia, Moldova and Ukraine - have an unbroken record as hybrid regimes, while the Central Asian republics of Tajikistan, Turkmenistan and Uzbekistan remain autocracies throughout the entire period.

Taking a closer look at the time-series data in Table 1.1, we see that regime transitions have taken place 21 times in 14 countries between 1992 and 2008. These instances of regime change are presented below.

Table 1.1: Instances of post-communist regime changes (1992-2008)

\begin{tabular}{|c|c|c|c|}
\hline $\begin{array}{l}\text { Change from hybrid } \\
\text { regime to } \\
\text { democracy }\end{array}$ & $\begin{array}{l}\text { Change from hybrid } \\
\text { regime to autocracy }\end{array}$ & $\begin{array}{l}\text { Change from } \\
\text { autocracy to hybrid } \\
\text { regime }\end{array}$ & $\begin{array}{l}\text { Change from } \\
\text { democracy to } \\
\text { hybrid regime }\end{array}$ \\
\hline Bulgaria 1992-93 & Azerbaijan 1992-93 & Bosnia 1995-96 & Bulgaria 1995-96 \\
\hline Lithuania 1992-93 & Kazakhstan 1993-94 & Azerbaijan 1996-97 & $\begin{array}{l}\text { Romania 2003- } \\
04\end{array}$ \\
\hline Estonia 1994-95 & Belarus 1995-96 & $\begin{array}{l}\text { Serbia-Mont. 1998- } \\
99\end{array}$ & \\
\hline Latvia 1994-95 & $\begin{array}{l}\text { Azerbaijan 1999- } \\
2000\end{array}$ & Kyrgyzstan 2004-05 & \\
\hline Romania 1996-97 & $\begin{array}{l}\text { Kyrgyzstan 1999- } \\
2000\end{array}$ & & \\
\hline Slovakia 1997-98 & Russia 2003-04 & & \\
\hline Croatia 2000-01 & & & \\
\hline Bulgaria 2000-01 & & & \\
\hline Romania 2004-05 & & & \\
\hline
\end{tabular}

Source: Linde and Ekman (2011).

Table 1.1 reveals that the most common direction of regime change is democratisation of a hybrid regime; nine times in seven countries. Two thirds of these transitions took place in the 1990s. The first decade of the 2000s saw only three instances of transition from hybrid regime to democracy, and two of these happened in 2000-2001.

It should be kept in mind that Table 1.1 depicts the situation from 1992 and onwards. The successful democratisation processes in Central Europe in 1989-1991 are thus not included in the table. All the same, it would seem that democratisation of post-communist regimes, even after 1991, has been a regional phenomenon. The successful democratising cases are found in the Balkan and Baltic countries, i.e. in regions with close ties to the West and the European Union. The three Baltic countries of Estonia, Latvia and Lithuania are in fact the only cases of successful post-Soviet transition to consolidated democracy. Ukraine is often held out as a supposedly 
successful example of post-Soviet democratisation; and Ukraine was indeed rated 'free' by Freedom House in 2006 in the wake of its so-called Orange Revolution. But it was a weak freedom rating of 2.5, and not sufficient to qualify for democracy status in the study by Linde and Ekman (2011; cf. Hale 2010). The positive trend towards a democracy based on the rule of law and respect for political civil rights was constantly challenged also after the Orange Revolution and in 2011 Freedom House moved Ukraine from 'free' to 'partly free' (see Chapter 21). In the final analysis, none of the socalled colour revolutions - the Rose Revolution in Georgia in 2003, the Orange Revolution in Ukraine in 2004 and the Tulip Revoultion in Kyrgyzstan in 2005 - fundamentally changed the post-Soviet record of authoritarianism.

The second column of Table 1.1 lends additional substance to the notion that hybrid regimes should not be seen as transitional regimes heading towards democracy. In the post-communist period we have seen regime changes from a hybrid regime to autocracy six times (in five countries). Here a regional pattern is also present, since all regime changes to authoritarianism have taken place in former Soviet republics, and most frequently during the 1990s. There are six instances of regime change to hybrid regimes; in four cases in the form of a liberalisation of autocratic regimes and in two cases in the form of a transition from democracy to hybrid regimes.

At first glance, post-communist hybrid regimes thus seem to be relatively unstable political entities. But for six of the 29 post-communist states the hybrid regime type was a quasi-permanent option. Albania, Armenia, Georgia, Macedonia, Moldova and Ukraine were classified as hybrid regimes throughout the entire time period under investigation (Linde and Ekman 2011).

\section{Contemporary Democracies, Autocracies and Hybrid Regimes}

There are several democratisation indices on the market that will tell about the same story as the one depicted in Figure 1.1. In Table 1.2 we have summarised the most recent country raknings provided by Freedom House to give a snapshot of situation today. Using the same cut-offs as Linde and Ekman, we can identify 12 democracies, all included in this volume; seven clearcut autocracies, none of them included in this edition of the Handbook of Political Change in Eastern Europe; and a group of ten countries in the grey zone between democracy and autocracy, some of which are represented in the handbook. Listed as democracies are the the ten EU enlargement countries of 2004-2007 plus neighbouring Croatia and Serbia. More than two thirds of them qualify for democracy with a strong Freedom House score of 1 , indicated within parenthesis in the table; the remaining five 
democracies qualify with a weaker Freedom House rating of 2. Most of them are recent or very recent arrivals to democracy; but with scores between 1 and 2, Latvia has been a stable democracy since 1995.

Table 1.2: Democracies, hybrid regimes and autocracies in Eastern Europe, 2011

\begin{tabular}{|c|c|c|}
\hline $\begin{array}{l}\text { Democracies } \\
\text { ( Scores: 1-2) }\end{array}$ & $\begin{array}{l}\text { Hybrid regimes } \\
\text { (Scores: } 2.5-5 \text { ) }\end{array}$ & $\begin{array}{l}\text { Autocracies } \\
\text { (Scores: } 5.5-7 \text { ) }\end{array}$ \\
\hline $\begin{array}{l}\text { Czech Republic (1) } \\
\text { Estonia (1) } \\
\text { Hungary (1) } \\
\text { Lithuania (1) } \\
\text { Poland (1) } \\
\text { Slovakia (1) } \\
\text { Slovenia (1) } \\
\text { Bulgaria (2) } \\
\text { Croatia (2) } \\
\text { Latvia (2) } \\
\text { Romania (2) } \\
\text { Serbia (2) }\end{array}$ & $\begin{array}{l}\text { Montenegro (2.5) } \\
\text { Albania (3) } \\
\text { Macedonia (3) } \\
\text { Moldova (3) } \\
\text { Ukraine (3) } \\
\text { Bosnia Herzegovina (3.5) } \\
\text { Georgia (3.5) } \\
\text { Kosovo (4.5) } \\
\text { Armenia (5) } \\
\text { Kyrgyzstan (5) }\end{array}$ & $\begin{array}{l}\text { Azerbaijan (5.5) } \\
\text { Kazakhstan (5.5) } \\
\text { Russia (5.5) } \\
\text { Tajikistan (5.5) } \\
\text { Belarus (6.5) } \\
\text { Turkmenistan (7) } \\
\text { Uzbekistan (7) }\end{array}$ \\
\hline
\end{tabular}

Note: The classification in Table 1.2 is based on Freedom House ratings of the countries of the world on a seven-point scale running from strongly democratic (1) to strongly autocratic (7), but the cut-offs defining the regime types are those of Linde and Ekman (2011). Country scores are reported within parenthesis. The countries listed in bold are included in the present volume.

Source: Freedom House (2011), Freedom in the World; cf. Freedom House (2010).

The seven autocracies listed in the third column of the table also break down into are two distinct sub-groups - hardcore autocracies such as Belarus, Turkmenistan, and Uzbekistan versus a somewhat softer and gentler kind of authoritarianism in countries such as Azerbaijan, Russia, Kazakhstan, and Tajikistan. The three former have political regimes close to or on a par with that of North Korea, one of the most repressive political regimes ever and a straight 7 in the Freedom House ratings from 1972 and onwards. With freedom scores of 5.5, the four latter may be seen as bordering on the hybrid regimes. Azerbaijan crossed this border thrice between 1992 and 2000 (see Table 1.1), and may cross it again. Others might follow suit, including Russia with its relatively recent past as 'partly free'.

No less than ten of the 29 post-communist countries turn up as hybrid regimes in 2011. This is also a heterogeneous group but less so than the authoritarian regimes. Seven out of ten countries in this group have scores hovering around 3, including Montenegro with a score of 2.5 and Bosnia and Georgia both scoring 3.5. In this setting, Armenia, Kyrgyzstan, and Kosovo with scores in the range of $4.5-5$ are the deviant cases, perhaps 
suggesting that it might be advisable to count countries scoring 5 as autocracies and change the cut-offs between hybrid and autocratic regimes accordingly.

\section{Selection of Cases}

With the collapse of the communist regimes in Central and Eastern Europe in the late 1980s and early 1990s, and the dissolution of the Soviet Union, the artificial division of Europe into one democratic Western part and one communist Eastern part became obsolete. If the 'Soviet bloc' was a misnomer, falsely indicating a homogenous entity of states, contemporary 'Eastern Europe' is something of a misnomer as well, considering that developments in different parts of the region have been quite diverse, as we have demonstrated above. It thus makes little sense to lump all of the "postcommunist states' together, despite a common history of 40 years or more of communist rule (cf. Berglund, Ekman and Aarebrot 2004).

How should our sample of 19 countries be justified, then? In 1998, we argued that our ten-country sample largely reflected a wish only to include countries that had reached some level of political stability, in order for the analysis to be worthwhile (Berglund, Hellén and Aarebrot 1998, 4). In the second edition of the Handbook of Political Change in Eastern Europe (2004), focus was very much on democratic consolidation, and the inclusion of three less successful cases in this respect - Croatia, Serbia and Moldova - did not fundamentally change the validity of the same argument. The idea was to explicitly test the theoretical assumption about a link between political/democratic stability and the emergence of distinct political cleavages.

In this volume, we have chosen to include six additional cases, most of them far from being consolidated democracies: Georgia, Ukraine, Bosnia, Albania, Macedonia and Montenegro. Again, the idea is to focus on political cleavages as such, in the eastern part of Europe, implicitly testing some of the assumptions found in the literature on political cleavages, which is typically based on empirical observation of Western Europe. This volume is thus written within the tradition of comparative macro-sociology. As in the seminal book on cleavage structures edited by Seymour Martin Lipset and Stein Rokkan (1967), we focus primarily on the systems of contrasts and cleavages within national communities; on the factors important for development of a stable system of cleavages and opposition in national political life; and on the behaviour of rank-and-file citizens in the party-political systems. The historical dimension is important; as is the task of developmental comparison and the mapping of variations in the sequences of alternatives. As in the two previous versions of the Handbook of Political Change in Eastern Europe, the fundamental assumption in this 
volume is that cleavages matter. This does not necessarily lead to an analysis of democratic colsolidation; even if political cleavages are of obvious importance for the way democracy actually works, cleavages as such are also telling about the more general political development, in terms of parties, party systems and regime change. In other words, analysing cleavages is a way of making sense of different political regimes, in order to understand what makes them tick. Cleavages structure the behaviour of voters and parties alike and they determine the number of parties and the nature of partisan conflict. Consequently, not all cases included in such an analysis need to be consolidated democracies.

At the same time, considering the logic of political cleavages as the basis of a multi-party competitive (and thus democratic) political order, it makes little sense to include cases where there is little or no political competition. This speaks against all countries classified as 'autocracies' in Table 1.2, including Belarus and Russia. Belarus left the grey zone between democracy and authoritarianism and positioned itself squarely among the non-democratic regimes only a few years after the breakup of the Soviet Union. Russia's road towards autocracy was piecemeal and took an additional ten years (cf Table 1.1). The 19 countries included in this volume are primarily to be found in the first two columns of Table 1.2. The inclusion of all the countries listed as 'democracies' was an obvious choice. In addition, we decided to include the seven hybrid regimes with scores hovering around 3, i.e. in the range between 2.5 and 3.5. Hybrid regimes within this span are presumably closer to democracy than hybrid regimes with scores bordering on autocracy such as Armenia, Kyrgyzstan, and Kosovo (see Table 1.2).

The countries in the volume have yet another common denominator. They are all as it were within the sphere of influence of the European Union. The ten East European countries included in the EU enlargement wave of 2004 2007 are all listed as democracies. The additional democracies in Table 1.2 are soon to be members of the European Union. Croatia has been cleared for full membership in 2014; and - as we write this (2012) - Serbia is about to get candidate member status. Macedonia has had candidate member status since 2005; and its government has made full EU membership a strategic priority. The non-EU members in our sample are in fact united by a wish for closer cooperation with the EU, in most cases full membership. The message from Brussels has thus far been more favourable for applicants from the Balkan region than for seemingly far away applicants such as Moldova, Ukraine and Georgia (Berglund, Duvold, Ekman and Schymik 2009, 69109). Relations with the three latter have been relegated to the European Neighbourhood Policy (ENP) - a programme specifically designed by the EU for partners without prospects for full membership in the near future. 


\section{Structure of the Volume}

The country-specific chapters in this book are arranged roughly in order of the geographical north-south axis, starting off with the Baltic Seaboard countries, proceeding down through Central Europe, then moving eastwards through the Balkans towards the Black Sea, and concluding with the East European cases: Moldova in the north-east, bordering on Ukraine, and further to the east, Georgia.

This introductory chapter is followed by two framework chapters. The first of these (Chapter 2) ponders the relevance of the historical legacy in the central and eastern part of Europe. Which are the prerequisites for the consolidation of democracy? What are the long-term prospects for democracy in Central and Eastern Europe? What authoritarian legacies may be identified? The 19 subsequent country-specific chapters address similar topics, albeit and obviously from slightly varying perspectives.

Focusing on the concept of political cleavages, the following framework chapter (Chapter 3) offers a development of Seymour Martin Lipset and Stein Rokkan's classical account of 1967. Drawing on Bartolini and Mair (1990) and Knutsen and Scarbrough (1995) and others, Deegan-Krause suggests that cleavages are operative on three levels of analysis - the demographic level, the attitudinal level and the behavioural level. A 'full' cleavage thus requires an overlap on all three levels. For example, as a demographic category, 'workers' will have to display attitudinal and behavioural characteristics that set them apart from other social groups in order to qualify for cleavage politics along a left/right continuum. A partial overlap does not constitute a cleavage but a divide, and Deegan-Krause draws our attention to three such divides or partial cleavages - structural divides, issue divides, and caste divides.

The country-specific chapters in this volume (Chapters 4-22) will provide an overview of how cleavages and divides have made themselves felt after communism. Of particular interest is the extent to which there is a link between the cleavage structure and the emerging party systems. As mentioned above, Lipset and Rokkan have pointed out that the link between parties and cleavages is crucial for the development of stable party systems. The following chapters will demonstrate that most, if not all, Central and East European countries are still far from having established a cleavageparty linkage dominating the electoral arena. The party systems in the region are still in a state of flux, and electoral behaviour is characterised by a great deal of volatility. This makes the political systems vulnerable to various kinds of populist movements, including those of an anti-democratic hue. Even so, a historical perspective tells us that the prospects for consolidated democracy have never been better in Central and Eastern Europe than they are today.

To sum up this chapter, this revised and expanded edition of the 
Handbook of Political Change in Eastern Europe provides the reader with in-depth analyses of the political development in a broad range of countries in post-communist Europe. The country-specific chapters are written by scholars with well-documented area expertise on their respective cases. Each chapter includes appendices with detailed information about election results, government compositions, electoral laws and constitutional frameworks. In addition to these in-depth and up-to-date analyses of the East European party systems and emerging cleavage structures, the concluding chapter of this volume makes an attempt at synthesising the results of the country-specific analyses.

\section{REFERENCES}

Alexander, Marcus (2008), 'Democratization and Hybrid Regimes: Comparative Evidence from Southeast Europe', East European Politics and Society 22 (4), 928-954.

Bartolini, Stefano and Peter Mair (1990), Identity, Competition and Electoral Availability: The Stability of European Electorates, 1885-1985, Cambridge, Cambridge University Press.

Berglund, Sten and Joakim Ekman (2010), 'Cleavages and Political Transformation', in Stefan Immerfall and Göran Therborn, eds., Handbook of European Societies, New York, London and Heidelberg, Springer

Berglund, Sten, Kjetil Duvold, Joakim Ekman and Carsten Schymik (2009), Where Does Europe End: Borders, Limits and Directions of the EU, Cheltenham, Edward Elgar.

Berglund, Sten, Joakim Ekman and Frank Aarebrot (2004), 'The Diversity of Post-Communist Europe', in Sten Berglund, Joakim Ekman and Frank Aarebrot, eds., (2004), The Handbook of Political Change in Eastern Europe. Second Edition, Cheltenham, Edward Elgar.

Berglund, Sten, Joakim Ekman and Frank Aarebrot, eds., (2004), The Handbook of Political Change in Eastern Europe. Second Edition, Cheltenham, Edward Elgar.

Berglund, Sten, Tomas Hellén and Frank Aarebrot, eds., (1998), The Handbook of Political Change in Eastern Europe, Cheltenham, Edward Elgar.

Boogards, Matthijs (2009), 'How to Classify Hybrid Regimes: Defective Democracy and Electoral Authoritarianism', Democratization 16 (2), 399-423.

Carothers, Thomas (2002), 'The End of the Transition Paradigm', Journal of Democracy, 13 (1).

Case, William (2005), 'Southeast Asia's Hybrid Regimes: When Do Voters Change Them?', Journal of East Asian Studies 5 (2), 215-237.

Diamond, Larry (2002), 'Thinking about Hybrid Regimes', Journal of Democracy, 13 (2).

Ekman, Joakim (2009), 'Political Participation and Regime Stability: A Framework for Analyzing Hybrid Regimes', International Political Science Review, 30 (7), 7-31.

Freedom House (2010), Nations in Transit: Democratization from Central Europe to Eurasia, Lanham, MD, Rowman \& Littlefield Publishers.

Hadenius, Axel and Jan Teorell (2007), 'Pathways from Authoritarianism', Journal of Democracy, $18(1), 143-157$.

Hale, Henry (2010), 'The Uses of Divided Power', Journal of Democracy, 21 (3), 84-98.

Howard, Marc M. and Philip G. Roessler (2006), 'Liberalizing Electoral Outcomes in Competitive Authoritarian Regimes', American Journal of Political Science, 50 (2), 365-381.

Karl, Terry Lynn (1995), 'The Hybrid Regimes of Central America', Journal of Democracy, 6 (3), 72-86.

Knutsen, Oddbjørn and Elinor Scarbrough (1995), 'Cleavage Politics', in Jan van Deth, ed., The Impact of Values, Oxford, Oxford University Press.

Krause, Kevin D. 2004. 'Slovakia', in Sten Berglund, Joakim Ekman and Frank H. Aarebrot, eds., The Handbook of Political Change in Eastern Europe, Second Edition, Cheltenham, Edward Edgar.

Levitsky, Steven and Lucan A. Way (2010), Competitive Authoritarianism: Hybrid Regimes After the Cold War, Cambridge, Cambridge University Press. 
Levitsky, Steven and Lucan A. Way (2002), 'The Rise of Competitive Authoritarianism', Journal of Democracy, 13 (2), 51-65.

Linde, Jonas and Joakim Ekman (2011), 'Patterns of Stability and Performance in Post-Communist Hybrid Regimes', in Elisabeth Bakke and Ingo Peters, eds., 20 Years since the Fall of the Berlin Wall: Transitions, State-Breakup and Democratic Politics in Central Europe and Germany, Berlin, Berliner Wissenschafts-Verlag.

Lipset, Seymour Martin and Stein Rokkan, eds., (1967), Party Systems and Voter Alignments, New York, Free Press.

McFaul, Michael (2002), 'The Fourth Wave of Democracy and Dictatorship: Noncooperative Transitions in the Postcommunist World', World Politics 54, 212-44.

Merkel, Wolfgang (2004), 'Embedded and Defective Democracies', Democratization, 11 (5), 3358.

Morlino, Leonardo (2009), 'Are There Hybrid Regimes? Or are They Just an Optical Illusion?, European Political Science Review 1 (2), 273-296.

O'Donnell, Guillermo and Philippe Schmitter (1986), Transitions from Authoritarian Rule: Tentative Conclusions about Uncertain Democracies, Baltimore \& London, The Johns Hopkins University Press.

Roessler, Philip. G. and Marc M. Howard (2009), 'Post-Cold War Political Regimes: When Do Elections Matter?', in Staffan I. Lindberg, ed., Democratization by Elections: A New Mode of Transition, Baltimore, The Johns Hopkins University Press.

Ryan, Curtis R. and Jillian Schwedler (2004), 'Return to Democratization or New Hybrid Regime? The 2003 Elections in Jordan', Middle East Policy, 11 (2), 138-151.

Schedler, Andreas, ed., (2006), Electoral Authoritarianism: The Dynamics of Unfree Competition, Boulder, Lynne Rienner.

Schmitter, Philippe C. (1994), 'Dangers and Dilemmas of Democracy', Journal of Democracy, 5 (2), 57-74.

Schöpflin, George (1993), Politics in Eastern Europe 1945-92, Oxford, Blackwell.

Shevtsova, Lilia (2001), 'Russia’s Hybrid Regime', Journal of Democracy, 12 (4), 65-70.

Wang, Zhengxu (2009), 'Is China Becoming a Hybrid Regime?', paper presented at the Annual Meeting of the Midwest Political Science Association, Chicago, 2-5 April 2009.

Wheatley, Jonathan and Christoph Zürcher (2008), 'On the Origin and Consolidation of Hybrid Regimes: The State of Democracy in the Caucasus', Taiwan Journal of Democracy, 4 (1).

Whitefield, Steven (2002), 'Political Cleavages and Post-Communist Politics', Annual Review of Political Science 5, 181-299.

Wigell, Mikael (2008), 'Mapping "Hybrid Regimes": Regime Types and Concepts in Comparative Politics', Democratization, 15 (2), 230-250. 
Sten Berglund and Joakim Ekman - 9781782545880 Downloaded from PubFactory at 04/26/2023 01:18:06PM via free access 